\title{
Pengaruh Implementasi Model Pembelajaran Resolusi Konflik terhadap Sikap Religius dan Hasil Belajar Pkn Siswa
}

\author{
Ni Luh Desy Permini ${ }^{1 *}$, I Wayan Lasmawan ${ }^{2}$, Nyoman Dantes ${ }^{3}$ \\ 1,2,3 Program Studi Pendidikan Dasar, Program Pascasarjana Universitas Pendidikan Ganesha Singaraja, Indonesia
}

\author{
ARTICLEIN \\ $\mathrm{FO}$ \\ Article history: \\ Received 17 \\ November 2017 \\ Received in revised \\ form \\ 12 Desember 2017 \\ Accepted 15 Januari \\ 2018 \\ Available online 20 \\ Februari 2018 \\ Kata Kunci: \\ hasil belajar PKn, \\ model resolusi \\ konflik, sikap religius \\ Keywords: \\ Learning outcomes \\ of Civics, Conflict \\ Resolution Model, \\ Religius Attitudes
}

\begin{abstract}
A B S TR A K
Penelitian ini bertujuan untuk mengetahui pengaruh implementasi model pembelajaran resolusi konflik terhadap sikap religius dan hasil belajar PKn siswa kelas V SD. Penelitian eksperimen semu ini menggunakan rancangan Single Factor Independent Group Design. Populasi penelitian ini adalah siswa kelas V Gugus II Kecamatan Sawan sebanyak 150 siswa. Sampel penelitian berjumlah 62 siswa. Sampel penelitian adalah siswa kelas V SDN 1 Bebetin dan SDN 3 Bebetin yang diambil dengan teknik random sampling pada kelas-kelas yang setara. Data yang dikumpulkan adalah sikap religius dengan metode kuesioner dan hasil belajar PKn dengan tes objektif. Data dianalisis dengan menggunakan MANOVA. Hasil Penelitian menunjukkan bahwa: pertama, Hasil Belajar PKn siswa yang mengikuti implementasi model resolusi konflik lebih baik daripada siswa yang mengikuti pembelajaran dengan model konvensional $(F=266,796 ; p<$ $0,05)$; kedua, sikap religius siswa yang mengikuti model resolusi konflik lebih baik daripada siswa yang mengikuti pembelajaran dengan model konvensional $(F=114,275 ; p<0,05)$; ketiga, secara simultan sikap religius dan hasil belajar PKn antara siswa yang mengikuti model resolusi konflik lebih baik daripada siswa yang mengikuti model konvensional. Model konvensional yang digunakan dalam penelitian ini adalah metode ceramah.
\end{abstract}

\section{A B S TR A C T}

This study aimeds to determine the effect of the implementation of conflict resolution learning model on the attitude of religious and learning outcome of Civics students of grade $\mathrm{V}$ Elementary School this quasi experimental study using the design of Single Factor Independent Group Design .Population of this study is grade V student of cluster II Sawan is 150 students. The sample of this research is 62 students. The sample of this research are students of grade V of SDN 1 Bebetin and SDN 3 Bebetin taken by random sampling technique in the equivalent classes. The data collected werw the attitude of religious with questionnaire and the learning outcome with objective test of civics data were analyzed by using MANOVA. The result of the research showee that: first, the students learning outcome which followed the implementation of the conflict resolution model were better than the student who followed the learning with conventional model $(F=266.796, p<0,05)$; secondly students religios attitudes that follow conflict resolution models are better than student who follow learning with conventional models $(F=114.275, p<0,05)$; third, simultaneously the attitude of religios and learning outcome between student who follow conflict resolution model is better than students who follow the conventional model. The conventional model used in this research is the lecture method

\footnotetext{
* Corresponding author.

E-mail addresses: desy.permini@pasca.undiksha.ac.id (Desy Permini)
} 


\section{Pendahuluan}

Pendidikan merupakan suatu hal yang utama dan sangat penting untuk mendukung kemajuan bangsa Indonesia. Kemajuan suatu bangsa dapat dicerminkan dari tingkat kualitas pendidikannya, suatu bangsa dikatakan maju apabila semua warga negaranya mendapatkan pendidikan yang layak untuk meningkatkan taraf hidupnya. Hal ini sesuai dengan visi pendidikan nasional yang termuat dalam Peraturan Menteri Pendidikan Nasional nomor 41 tahun 2007 yang menyatakan, "terwujudnya sistem pendidikan sebagai pranata sosial yang kuat dan berwibawa untuk memberdayakan semua warga negara Indonesia berkembang menjadi manusia yang berkualitas sehingga mampu dan proaktif menjawab tantangan zaman yang selalu berubah".

Dalam proses pembelajaran Pendidikan Kewarganegaraan (PKn) selama ini, guru menerapkan pendekatan klasikal dan metode ceramah menjadi pilihan utama dalam pembelajaran. Pola pembelajaran PKn yang biasa dilaksanakan adalah (1) pembelajaran diawali penjelasan singkat materi oleh guru, siswa diajarkan teori yang harus dihafalkan, (2) pemberian contoh soal dan (3) diakhiri dengan latihan soal, dan pemberian tugas atau pekerjaan rumah (PR). Dalam latihan soal siswa, selalu diarahkan untuk menjawab "benar". Untuk setiap jawaban benar, kemampuan berpikir kritis (konvergen) siswa lebih ditekankan tanpa diberikan kesempatan kepada siswa untuk mengembangkan kemampuan berpikir (devergen). Pola model pembelajaran konvensional yang dilaksanakan secara monoton dari waktu ke waktu. Pembelajaran tersebut merupakan konsep yang diterima siswa hampir semuanya berasal dari "apa kata guru".

Pendidikan karakter pada saat ini menjadi tujuan utama pendidikan pada semua tingkat pendidikan, yakni dari Sekolah Dasar hingga Perguruan Tinggi. Seperti yang termuat dalam UndangUndang Sistem Pendidikan Nasional No. 20 tahun 2003 Bab 2 Pasal 3 bahwa "Pendidikan nasional berfungsi mengembangkan kemampuan dan membentuk watak serta peradaban bangsa yang bermartabat dalam rangka mencerdaskan kehidupan bangsa, bertujuan untuk berkembangnya potensi peserta didik agar menjadi manusia yang beriman dan bertakwa kepada Tuhan Yang Maha Esa, berakhlak mulia, sehat, berilmu, cakap, kreatif, mandiri, dan menjadi warga negara yang demokratis serta bertanggung jawab". Akan tetapi pada kenyataannya proses pendidikan tahap tertentu dianggap selesai dengan hasil ujian dan selesainya pemberian materi, padahal tujuan pendidikan lebih menekankan pada karakter bukan dalam bentuk skor yang tidak mencerminkan atau bertolak belakang dengan perilaku/ sikap nyata peserta didik/lulusan.

Salah satu sikap yang disarankan adalah sikap religius. Sikap religius muncul karena kebiasaan (habituation) tentang hal yang baik, sehingga peserta didik menjadi paham (domain kognitif) tentang mana yang baik dan salah, maupun merasakan (domain afektif) nilai yang baik dan biasa melakukannya (domain perilaku). Jadi sikap religius terkait erat kaitannya dengan "habit" atau kebiasaan yang terus menerus dipraktikkan atau dilaksanakan. Jika seseorang berperilaku tidak jujur, kejam, atau rakus, dapat dinyatakan bahwa orang tersebut memanifestasikan perilaku buruk. Sebaliknya, apabila seseorang berperilaku jujur, bertanggung jawab, suka menolong, sikap perilaku orang tersebut memanifestasikan karakter mulia yang merupakan pencerminan dari sikap religius.

Berdasarkan teori dan kenyataan itulah, peneliti sangat tertarik untuk mengadakan penelitian guna melihat pengaruh implementasi model pembelajaran resolusi konflik dalam pembelajaran Pendidikan Kewarganegaraan tidak serta merta dipengaruhi oleh faktor pemilihan dan penggunaan pendekatan pembelajaran oleh guru, juga di pengaruhi oleh faktor internal siswa seperti aspek psikologi diantaranya sikap. Sikap yang dimaksud adalah sikap religius. Sedangkan tugas PKn dalam paradigma barunya mengembangkan pendidikan demokrasi mengemban tiga fungsi pokok, yakni mengemban kecerdasan warga negara (civic intelligence), membina tanggung jawab warga negara (civic responsibility), dan mendorong partisipasi warga negara (civic participation). Dengan tiga fungsi pokok tersebut dapat tercapai melalui pelaksanaan sikap religius. Untuk itu di pandang perlu diadakan penelitian lebih seksama tentang "Pengaruh Implementasi Model Pembelajaran Resolusi Konflik Terhadap Sikap Religius dan Hasil Belajar PKn Siswa Kelas V Sekolah Dasar Gugus II Kecamatan Sawan Kabupaten Buleleng”.

Fungsi Mata pelajaran PKn seperti yang termuat dalam KTSP (2011:13) adalah sebagai berikut: (1) melestarikan dan mengembangkan nilai moral Pancasila secara dinamis dan terbuka, yaitu nilai moral Pancasila yang dikembangkan itu mampu menjawab tantangan perkembangan yang terjadi dalam masyarakat, tanpa kehilangan jati diri sebagai bangsa Indonesia, yang merdeka, bersatu, dan berdaulat, (2) mengembangkan dan membina siswa menuju manusia Indonesia seutuhnya yang sadar politik, hukum dan konstitusi negara kesatuan Republik Indonesia berlandaskan Pancasila, (3) membina pemahaman dan kesadaran terhadap hubungan antara warga negara dan negara, antara warga negara dengan sesama warga negara dan pendidikan pendahuluan bela negara agar mengetahui dan mampu melaksanakan dengan baik hak dan kewajiban sebagai warga negara, dan (4) membekali siswa dengan sikap dan perilaku yang berdasarkan nilai-nilai moral Pancasila dan UUD 1945 dalam kehidupan sehari-hari. UUD 
1945 yang dimaksudkan dalam hal ini adalah UUD 1945 yang sudah diamandemen oleh Majelis Permusyawaratan Rakyat (MPR).

Menurut Ancok \& Suroso (2001) menyatakan bahwa religiusitas merupakan perilaku terhadap agama yang berupa penghayatan terhadap nilai-nilai agama yang dapat ditandai tidak hanya melalui ketaatan dalam menjalankan ibadah ritual tetapi juga dengan adanya keyakinan, pengalaman, dan pengetahuan mengenai agama yang dianutnya.

Berdasarkan kajian teori di atas meneliti tentang sikap religiusitas, dalam penelitian ini menggunakan dasar teori gabungan antara Ancok dan Suroso yang menyatakan bahwa religiusitas adalah kedalaman penghayatan keagamaan seseorang dan keyakinannya terhadap adanya tuhan yang diwujudkan dengan mematuhi perintah dan menjauhi larangan dengan kaiklasan hati dan dengan seluruh jiwa dan raga yang rangkum dalam 5 dimensi keberagamaan.

National Commission of Social Studies (NCSS).di USA mendefinisikan MRK sebagai "the teaching and learning of Civic Education in the context of real societies" (NCSS, 2003).

Langkah- langkah MRK yaitu tahap identifikasi, eksplorasi, eksplansi, negosiasi konflik, dan resolusi konflik (Lasmawan, 2012).

Berdasarkan kajian teori di atas meneliti tentang model pembelajaran resolusi konflik, dalam penelitian ini menggunakan dasar teori gabungan antara NCSS dan Lasmawan yang mengemukakan bahwa model resolusi konflik adalah model pembelajaran yang menekankan pengalaman langsung kepada siswa dalam memecahkan permasalahan sosial budaya di masyarakat. Dimana langkah model pembelajaran resolusi konflik terdiri dari 5 langkah yaitu identifikasi, eksplorasi, eksplansi, negosiasi konflik, dan resolusi konflik.

\section{Metode}

Rancangan penelitian yang digunakan adalah rancangan penelitian penelitian eksperimen semu dalam bentuk Single Factor Independent Group Design. Populasi dalam penelitian ini adalah siswa Kelas V, Gugus II yang terdiri dari SD. Negeri 1 Bebetin, SD. Negeri 2 Bebetin, SD. Negeri 3 Bebetin, dan SD Negeri 4 Bebetin, Negeri 5 Bebetin, Negeri 2 Galungan, Kecamatan Sawan, Kabupaten Buleleng Tahun Pelajaran 2017/2018 yang berjumlah 6 Sekolah Dasar Negeri.

Berdasarkan dari karakteristik populasi dan tidak bisa dilakukan pengacakan individu, maka pengambilan sampel pada penelitian ini dengan teknik random sampling. Semua populasi dijadikan sampel dan dilakukan uji kesetaraan. Sebelum diadakan pengambilan sampel, terlebih dahulu dilakukan pengujian kesetaraan kelas berdasarkan nilai ulangan akhir semester II, untuk lebih meyakinkan kedua kelompok yang menjadi sampel tidak berbeda secara signifikan. Hasil belajar yang diperoleh kemudian dianalisis dengan uji-t.

Hasil pemilihan secara random menunjukan bahwa siswa kelas V SDN 1 Bebetin yang secara keseluruhan berjumlah 31 siswa terpilih menjadi sampel untuk kelas eksperimen. Sedangkan, bahwa siswa kelas V SDN 3 Bebetin yang secara keseluruhan berjumlah 31 siswa terpilih menjadi sampel untuk kelas kontrol. Maka dari itu, di ketahui bahwa jumlah total sampel yang digunakan dalam penelitian ini adalah 62.

Varabel bebas penelitin ini yaitu model resolusi konflik sedangkan variabel terikatnya berupa sikap religius dan hasil belajar PKn. Teknik pengumpulan data yang digunakan dalam penelitian ini adalah teknik tes dan kuesioner. Teknik tes digunakan untuk mengambil data hasil belajar PKn, teknik non-tes dalam penelitian ini dengan menggunakan lembar kuesioner sikap religius siswa dengan modifikasi dari skala Likert.

Sebelum instrument digunakan, maka dilakukan validasi dari masing- masing instrument. Untuk uji validasi isi dikonsultasikan dahulu kepada pakar (Judges) untuk dilakukan penilaian. Setelah pengujian oleh pakar (judges), selanjutnya instrument yang disusun baik kuesioner sikap religius dan tes hasil belajar PKn dilakukan uji empiris pada kelas V di gugus VIII Kecamatan Sawan. Datanya dianalisis dengan menggunakan korelasi product moment. Setelah dianalisis, dari 40 pernyataan terdapat 31 pernyataan pada kuesioner valid. Realibilitas kuesioner sikap religious menggunakan rumus alpa cronbach dengan bantuan Microsoft excel. Validitas instrument tes hasil belajar PKn menggunakan rumus korelasi Point Biserial ( $\mathrm{r}_{\mathrm{pbi}}$ ) dengan bantuan Microsoft excel. Realibilitas tes hasil belajar PKn menggunakan KR-20.

Dalam penelitian ini data disajikan dalam bentuk grafik histogram. Teknik yang digunakan untuk menganalisis data guna menguji hipotesis penelitian adalah MANOVA. Sebelum dilakukan analisis data, maka dilakukan uji normalitas sebaran data dengan menggunakan uji Kolmogorov-smirnov, uji homogenitas varians dengan uji Levene's, dan uji korelasi antar variabel terikat (kolinieritas) dengan menggunakan product moment. 


\section{Hasil dan Pembahasan}

Hasil Analisis Data

Dari rincian data tentang model resolusi konflik, data tentang model pembelajaran konvensional, data sikap religius siswa, dan data hasil belajar siswa tersebut diperoleh deskripsi data secara umum sebagai berikut.

Tabel 1. Rekapitulasi Hasil Perhitungan tentang Sikap Religius dan Hasil Belajar Kelompok Siswa yang Mengikuti Model Resolusi Konflik dan Kelompok yang Mengikuti Model Pembelajaran Konvensional

\begin{tabular}{lcccc}
\hline Statistik & \multicolumn{4}{c}{ Variabel } \\
\cline { 2 - 5 } & A1Y1 & A2Y1 & A1Y2 & A2Y2 \\
\hline Mean & 123,87 & 106,40 & 24,47 & 12,50 \\
Median & 125,00 & 106,00 & 25,00 & 12,50 \\
Standar Deviasi & 5,85 & 6,77 & 2,93 & 2,74 \\
Varians & 34,26 & 45,83 & 8,60 & 7,50 \\
Skor Minimum & 114 & 95 & 18 & 6 \\
Skor Maksimum & 133 & 120 & 29 & 16 \\
Jangkauan/Rentangan & 19,00 & 25,00 & 11,00 & 10,00 \\
\hline
\end{tabular}

Data tentang sikap religius yang mengikuti pembelajaran dengan model pembelajaran resolusi konflik mempunyai rentangan $=19, \mathrm{n}=30$, skor minimum $=114$, skor maksimum $=133$, banyak kelas interval $=6$, panjang kelas interval $=4$, rata-rata $=123,87$, median $=125$, standar deviasi $=5,85$, dan varians $=34,26$ Agar tampak lebih jelas, maka data pada tabel di atas dapat diringkas seperti gambar berikut ini.

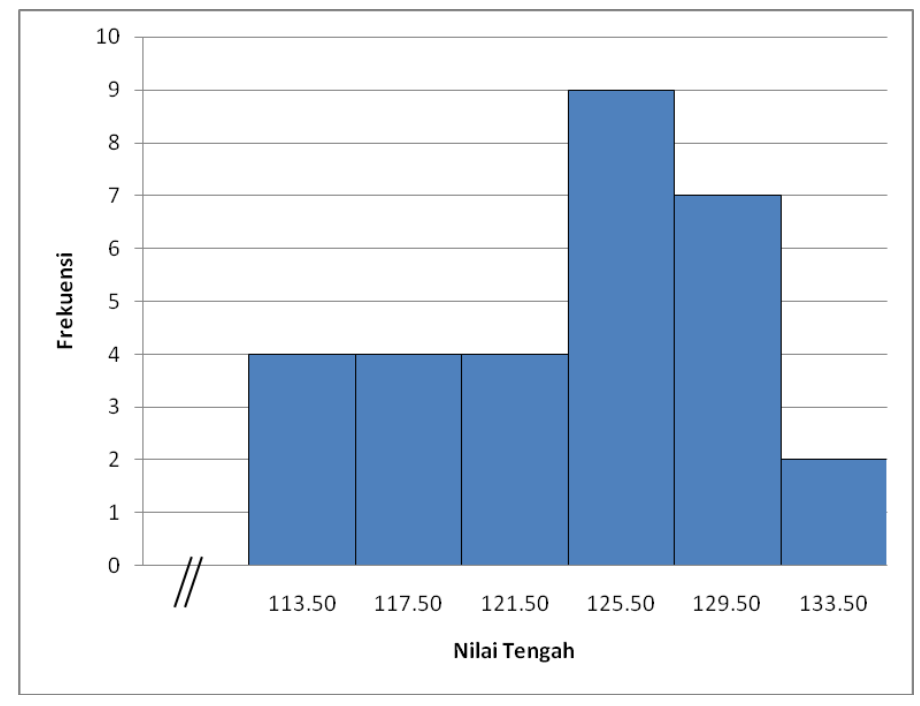

Gambar 1. Histogram Data Sikap Religius Siswa yang Mengikuti Model Resolusi Konflik (A1Y1).

Jika dilihat dari rata-rata (mean) $=123,87$ dan dikonversikan ke dalam tabel di atas, dapat diketahui bahwa kencederungan data sikap religius siswa yang mengikuti model resolusi konflik masuk dalam kategori sangat tinggi. Data tentang sikap religius yang mengikuti pembelajaran dengan model pembelajaran konvensional mempunyai rentangan $=25, \mathrm{n}=30$, skor minimum $=95$, skor maksimum $=$ 120 , banyak kelas interval $=6$, panjang kelas interval $=5$, rata-rata $=106,4$, median $=106$, standar deviasi $=6,77$, dan varians $=45,83$. Agar tampak lebih jelas, maka data pada tabel di atas dapat diringkas seperti gambar berikut ini. 


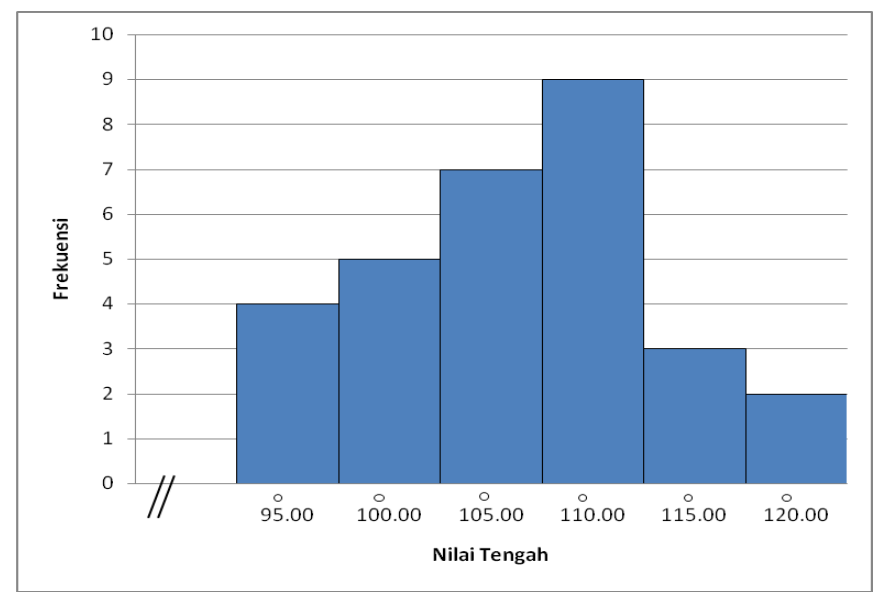

Gambar 2. Histogram Sikap Religius Siswa yang Mengikuti Model Pembelajaran Konvensional (A2Y1).

Jika dilihat dari rata-rata (mean) $=106,4$ dan dikonversikan ke dalam tabel di atas, dapat diketahui bahwa kencederungan data sikap religius siswa yang mengikuti model pembelajaran konvensional masuk dalam kategori sedang.

Data tentang hasil belajar yang mengikuti pembelajaran dengan model pembelajaran resolusi konflik mempunyai rentangan $=11, \mathrm{n}=30$, skor minimum $=18$, skor maksimum $=29$, banyak kelas interval $=6$, panjang kelas interval $=2$, rata-rata $=24,47$, median $=25$, standar deviasi $=2,93$, dan varians $=8,6$. Agar tampak lebih jelas, maka data pada tabel di atas dapat diringkas seperti gambar berikut ini.

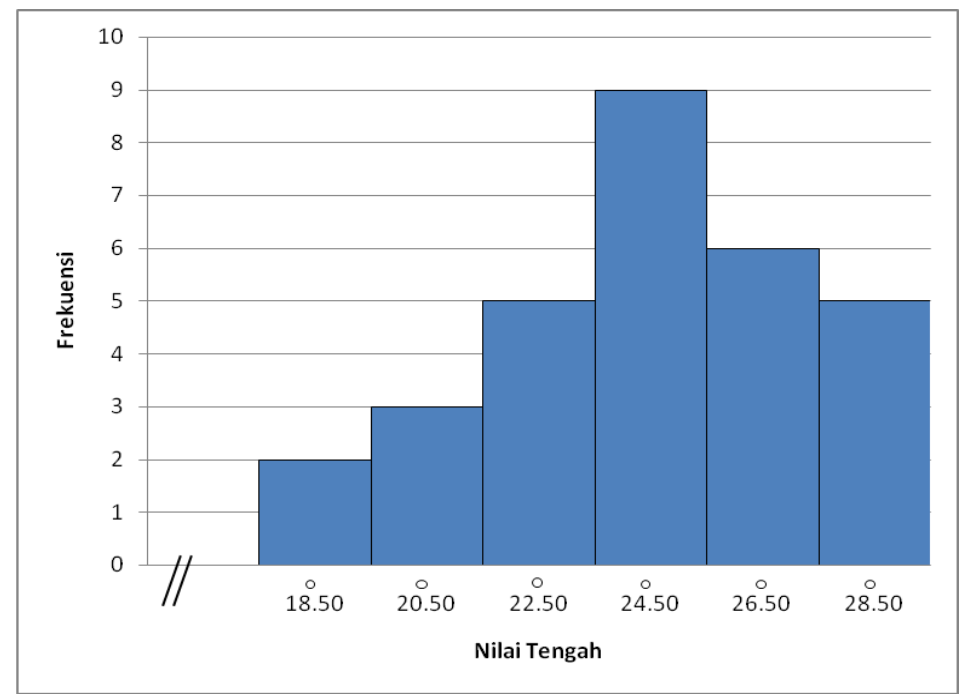

Gambar 3. Histogram Hasil belajar Siswa yang Mengikuti Model Resolusi Konflik (A1Y2).

Berdasarkan rata-rata (mean) $=24,47$ dan dikonversikan ke dalam tabel di atas, dapat diketahui bahwa kencederungan data data hasil belajar siswa yang mengikuti model resolusi konflik masuk dalam kategori sangat tinggi.

Data tentang hasil belajar yang mengikuti pembelajaran dengan model pembelajaran konvensional mempunyai rentangan $=10, \mathrm{n}=30$, skor minimum $=6$, skor maksimum $=16$, banyak kelas interval $=6$, panjang kelas interval $=2$, rata-rata $=12,5$, median $=12,5$, standar deviasi $=2,74$, dan varians $=7,5$. Agar lebih jelas dapat digambarkan pada grafik histogram berikut. 


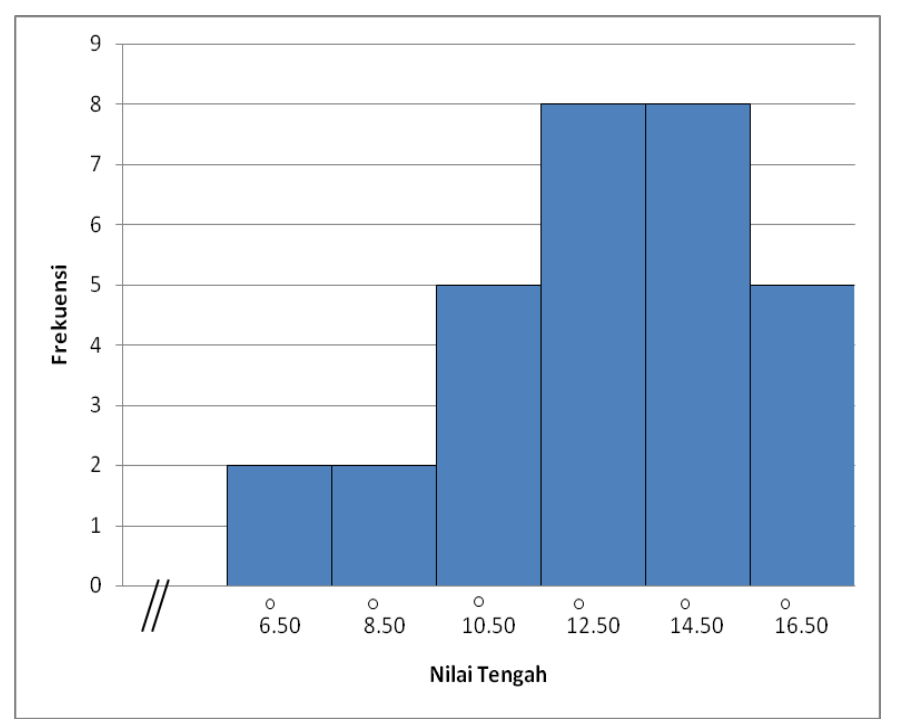

Gambar 4. Histogram Hasil Belajar Siswa yang Mengikuti Model Pembelajaran Konvensional (A2Y2).

Berdasarkan rata-rata (mean) = 12,50 dan dikonversikan ke dalam tabel di atas, dapat diketahui bahwa kencederungan data hasil belajar siswa yang mengikuti model pembelajaran konvensional masuk dalam kategori tinggi.

Perbedaan Hasil Belajar PKn antara Siswa yang Mengikuti Model Pembelajaran Resolusi Konflik dengan Siswa yang Mengikuti Model Pembelajaran Konvensional

Berdasarkan hasil analisis, diketahui bahwa data hasil belajar siswa yang mengikuti model pembelajaran resolusi konflik dengan rerata $=24,47$ masuk dalam kategori sangat tinggi dan yang megikuti pembelajaran dengan model pembelajaran konvensional dengan rerata $=12,50$ masuk dalam kategori sedang. Maka dari itu, dapat disimpulkan bahwa terdapat perbedaan hasil belajar yang signifikan antara kelompok siswa yang mengikuti pembelajaran dengan model resolusi konflik dengan kelompok siswa yang mengikuti pembelajaran dengan model pembelajaran konvensional.

Pengujian hipotesis pertama, hipotesis nul ditolak dan hipotesis alternatif diterima. Ini bermakna terdapat perbedaan hasil belajar yang signifikan antara kelompok siswa yang menggunakan model resolusi konflik dengan kelompok siswa yang menggunakan model pembelajaran konvensional.

Hasil penelitian ini diperkuat oleh penelitian yang dilakukan oleh Ni Putu Sugiantari pada tahun 2013 dengan judul penelitian "Pengaruh Implementasi Model Resolusi Konflik Terhadap Sikap Sosial dan Prestasi Belajar IPS pada siswa Kelas V SD Gugus 2 Sahadewa di Lelateng", ditemukan bahwa terdapat perbedaan rata- rata skor sikap sosial dengan prestasi belajar IPS yang signifikan antara kelompok siswa dengan model pembelajaran resolusi konflik dibandingkan dengan model pembelajaran konvensional.

Perbedaan Sikap Religius antara Siswa yang Mengikuti Model Pembelajaran Resolusi Konflik dengan Siswa yang Mengikuti Model Pembelajaran Konvensional. Berdasarkan hasil analisis diketahui bahwa data sikap religius siswa yang mengikuti model pembelajaran resolusi konflik dengan rerata 123,87 masuk dalam kategori sangat tinggi dan yang megikuti model pembelajaran konvensional dengan rerata 106,40 masuk dalam kategori tinggi. Maka dari itu, dapat disimpulkan bahwa terdapat perbedaan sikap religius yang signifikan antara kelompok siswa yang menggunakan model resolusi konflik dengan kelompok siswa yang menggunakan model pembelajaran konvensional.

Penelitian lain yang mendukung temuan ini adalah Widiarta (2013) yang menyatakan bahwa model pembelajaran Resolusi Konflik membawa pengaruh yang signifikan daripada pembelajaran konvensional dilihat dari prestasi belajar dan sikap demokrasi siswa. Penelitian lainnya yang mendukung temuan ini adalah Indra Kusuma (2017) yang berjudul " Pengaruh model pembelajaran resolusi konflik terhadap hasil belajar PKn ditinjau dari sikap sosial siswa kelas V SD Gugus Kolonel I Gusti Ngurah Rai Denpasar Utara" yang menyatakan bahwa, terdapat perbedaan sikap sosial dan hasil belajar dalam pembelajaran PKn secara signifikan antara siswa yang belajar dengan menggunakan model resolusi konflik dan model pembelajaran konvensional.

Hasil analisis menunjukan bahwa harga F adalah 184,202 untuk Pillai's Trace, Wilks' Lambda, Hotelling's Trace, dan Roy's Largest Root memiliki nilai signifikansi lebih kecil daripada 0,05. Maka dari itu, harga F untuk Pillai's Trace, Wilks' Lambda, Hotelling's Trace, dan Roy's Largest Root signifikan. Jadi, dapat disimpulkan bahwa terdapat perbedaan hasil belajardan sikap religius yang signifikan antara kelompok 
siswa yang menggunakan model resolusi konflik dengan kelompok siswa yang menggunakan model pembelajaran konvensional.

Dapat dijelaskan bahwa, berdasarkan hipotesis yang ada dapat diuraikan sebagai berikut. Hasil penelitian yang pertama menunjukkan bahwa terdapat perbedaan hasil belajar Pkn siswa yang mengikuti model pembelajaran Resolusi Konflik dengan siswa yang mengikuti model pembelajaran konvensional. Rekapitulasi data telah membuktikan bahwa adanya perbedaan hasil belajar PKn siswa, yaitu hasil belajar siswa yang mengikuti pembelajaran dengan model pembelajaran Resolusi Konflik lebih baik dibandingkan dengan siswa yang mengikuti pembelajaran konvensional. Hal ini ditunjukkan dengan nilai rata-rata hasil belajar PKn siswa yang mengikuti pembelajaran dengan model pembelajaran Resolusi Konflik dengan skor rata-rata 24,47 lebih tinggi daripada siswa yang mengikuti pembelajaran dengan pembelajaran konvensional dengan skor rata-rata 12,50 .

Berdasarkan uraian di atas dapat ditentukan bahwa siswa yang mengikuti pembelajaran dengan model pembelajaran Resolusi Konflik mempunyai hasil belajar PKn yang berbeda dengan siswa yang mengikuti pembelajaran konvensional. Jadi dapat disimpulkan bahwa terdapat perbedaan yang signifikan hasil belajar PKn antara siswa yang mengikuti pembelajaran dengan model pembelajaran Resolusi Konflik dan siswa yang mengikuti pembelajaran dengan pembelajaran konvensional pada mata pelajaran PKn siswa kelas V Sekolah Dasar Gugus II Kecamatan Sawan.

Hipotesis kedua, hasil uji hipotesis kedua berhasil menolak $\mathrm{H}_{0}$ yang menyatakan terdapat perbedaan sikap religius dalam pembelajaran PKn antara siswa yang mengikuti model pembelajaran Resolusi Konflik dengan siswa yang mengikuti model pembelajaran konvensional pada siswa kelas $\mathrm{V}$ Sekolah Dasar Gugus II Kecamatan Sawan Kabupaten Buleleng. Dengan demikian terdapat perbedaan sikap religius antara siswa yang mengikuti model pembelajaran Resolusi Konflik dengan siswa yang mengikuti model pembelajaran konvensional. Hasil penelitian menunjukkan bahwa sikap religius siswa yang mengikuti pembelajaran dengan model pembelajaran Resolusi Konflik lebih baik dibandingkan dengan siswa yang mengikuti pembelajaran konvensional.

Berdasarkan hasil analisis data telah terbukti bahwa terdapat perbedaan sikap religius, yaitu sikap religius siswa yang mengikuti model pembelajaran Resolusi Konflik lebih baik dibandingkan dengan siswa yang mengikuti pembelajaran konvensional. Hal ini ditunjukkan dengan rata-rata sikap religius siswa yang mengikuti pembelajaran dengan model pembelajaran Resolusi Konflik dengan skor rata-rata 123,87 lebih tinggi daripada rata-rata sikap religius siswa yang mengikuti pembelajaran konvensional dengan skor rata-rata 106,40. Jadi dalam perbandingan antara model pembelajaran Resolusi Konflik dengan pembelajaran konvensional, terdapat pengaruh model pembelajaran Resolusi Konflik terhadap sikap religius siswa. Pada dasarnya, terdapat perbedaan antara model pembelajaran Resolusi Konflik dengan model pembelajaran konvensional dalam pembelajaran PKn.

Temuan penelitian yang ketiga adalah secara simultan terdapat perbedaan sikap religius dan hasil belajar PKn antara siswa yang mengikuti model pebelajaran Resolusi Konflik dengan siswa yang mengikuti model pembelajaran konvensional. Hal ini disebabkan tahapan-tahapan dari model pembelajaran Resolusi Konflik dapat mengembangkan sikap Religius dan hasil belajar PKn. Berdasarkan hasil analisis dengan menggunakan model pembelajaran resolusi konflik statistik MANOVA dengan bantuan aplikasi SPSS diatas, hasil pengujian hipotesis dalam penelitian ini dapat diringkas sebagai berikut:

Pengujian hipotesis pertama, hipotesis nul ditolak dan hipotesis alternatif diterima. Ini bermakna terdapat perbedaan hasil belajar yang signifikan antara kelompok siswa yang menggunakan model resolusi konflik dengan kelompok siswa yang menggunakan model pembelajaran konvensional. Pengujian hipotesis kedua, hipotesis nul ditolak dan hipotesis alternatif diterima. Ini bermakna terdapat perbedaan sikap religius yang signifikan antara kelompok siswa yang menggunakan model resolusi konflik dengan kelompok siswa yang menggunakan model pembelajaran konvensional.

Pengujian hipotesis ketiga, hipotesis nul ditolak dan hipotesis alternatif diterima. Ini bermakna terdapat perbedaan hasil belajar dan sikap religius yang signifikan antara kelompok siswa yang menggunakan model resolusi konflik dengan kelompok siswa yang menggunakan model pembelajaran konvensional. Berdasarkan hasil penelitian di atas, dapat disimpulkan bahwa model pembelajaran resolusi konflik sangat efektif diterapkan untuk meningkatkan sikap religius siswa.

\section{Simpulan dan Saran}

Secara umum penelitian ini bertujuan untuk mengetahui perbedaan model pembelajaran Resolusi Konflik terhadap sikap religius dan hasil belajar PKn siswa kelas V Sekolah Dasar Gugus II Kecamatan Sawan,Kabupaten Buleleng. Penelitian ini dilaksanakan karena permasalahan bahwa sikap religius dan hasil belajar PKn siswa secara umum masih rendah, masih banyak siswa mengalami kesulitan dalam 
belajarnya, sehingga diperlukan upaya-upaya untuk memperbaikinya. Salah satu upaya penting yang harus segera dilakukan guru adalah melalui perbaikan model, metode, atau model pembelajaran yang digunakan guru sehingga pengertian siswa terhadap konsep PKn yang diajarkan menjadi kuat dan hasil belajarnya meningkat.

Berdasarkan hasil penelitian di atas, maka dapat disajikan beberapa saran untuk meningkatkan kualitas pembelajaran selanjutnya. Pertama, hasil penelitian menunjukkan bahwa siswa yang mengikuti proses pembelajaran dengan model pembelajaran Resulsi Konflik secara signifikan memiliki sikap religius yang lebih tinggi daripada siswa yang mengikuti pembelajaran konvensional. Maka dari itu, guru hendaknya menggunakan model pembelajaran Resolusi Konflik dalam pembelajaran untuk meningkatkan sikap religius siswa. Kedua, hasil penelitian menunjukkan bahwa siswa yang mengikuti proses pembelajaran dengan model pembelajaran Resolusi Konflik secara signifikan memiliki hasil belajar PKn yang lebih tinggi daripada siswa yang mengikuti pembelajaran konvensional. Maka dari itu, hendaknya menggunakan model pembelajaran Resolusi Konflik dalam pembelajaran untuk meningkatkan hasil belajar PKn. Ketiga, mengingat keterbatasan waktu dan pokok bahasan yang diperlukan dalam penelitian ini maka disarankan kepada peneliti lain untuk melakukan penelitian sejenis dengan materi pembelajaran yang berbeda dan waktu yang lebih lama agar mendapatkan gambaran yang lebih tepat mengenai model pembelajaran Resolusi Konflik terhadap sikap religius dan hasil belajar PKn. Keempat, penelitian ini difokuskan untuk mengetahui perbedaan model pembelajaran Resolusi Konflik terhadap sikap religius dan hasil belajar PKn, sehingga disarankan kepada peneliti lain untuk mengadakan penelitian lebih lanjut dengan menggunakan variabel-variabel yang lain.

\section{Daftar Rujukan}

Depdiknas. 2006. Kurikulum tingkat Satuan Pendidikan. Jakarta: Depdiknas.

Indra, K. P. 2017. "Pengaruh Model Pembelajaran Resolusi Konflik terhadap Hasil Belajar PKn dan Sikap Sosial Siswa Kelas V SD Gugus Kolonel I Gusti Ngurah Rai Denpasar Utara". Jurnal Penelitian Pascasarjana Undiksha, Volume 14 Nomor 3, (2017). Tersedia pada http://pasca.undiksha.ac.id/ejournal/index.php/jurnal_pendas/article/view/510.Diunduh tanggal, 2 Januari 2018.

Kawiyasa, I.M. 2012. "Pengaruh Penerapan dan Pengelolaan Resolusi Konflik terhadap Prestasi Belajar Pendidikan Kewarganegaraan ditinjau dari sikap religiusitas dan sikap sosial Siswa". Artikel Penelitian (2012). Tersedia pada http://jurnal_pendas/article/view/510.Diunduh tanggal, 2 Juni 2017.

Lasmawan, W. 2008.Materi Perkuliahan PPKn SD. Singaraja : Undiksha Singaraja

Malihah, E.2015." Teaching Conflict Resolution Through General Education of University:Presparing Students to Prevent or Resolve Conflict in a Pluralistic Society”. Jurnal at Canadian Center of Science and Education, Volume $11 \quad$ No 12 (2015). Tersedia pada http://dx.doi.org/10.5539/ass.v11n12p353/Asian social Science. Di unduh pada tanggal 2 Juli 2017

NCSS.2003. Science-Technology-Society (STS) in Social Studies :Position Paper. Washington DC. NCSS.

NCSS.2005. Guedelines for Teaching About Science/Technology/Society in Social Studies : Education for Citizenship in The 21 st Centry. (One Line).Available at http:www.uow.edu.au/sts/ncss/pubs/oonvt.html.

Widiarta, K. 2015. “Pengaruh Model Pembelajaran Resolusi Konflik Terhadap Prestasi Belajar Pkn Ditinjau Dari Sikap Demokrasi Siswa Kelas VI Di Gugus 1 Kecamatan Sukasada". Jurnal Penelitian Pascasarjana Undiksha, Volume 3, (2015). Tersedia pada http://pasca.undiksha.ac.id/ejournal/index.php/jurnal_pendas/article/view/510.Diunduh tanggal, 3 Juni 2017 